\title{
Another piece of paper without force
}

\author{
This week's Start II treaty signed in Moscow is little more than wishful thinking, at least while it lacks the support \\ of other ex-Soviet republics than Russia.
}

IN years past, an agreement between the United States and Russia to dispense with two-thirds of existing nuclear weapons would be hailed as the beginning of a new era of peace and tranquillity. But that reading cannot be wrung from the signing ceremony last Sunday in Moscow of the treaty called Start II. President Boris Yeltsin of Russia, bruised by last month's congress, would have welcomed the chance to appear, yet again, as a personage of international importance, while President George Bush of the United States was no doubt alert to the history books that will engulf him on Inauguration Day, 20 January.

Start II is a splendid piece of paper, but it will be a dead letter until ratified not only by the Russian Congress, but by the other de facto nuclear weapons states of the Commonwealth of Independent States (CIS), the constitutional legatee of what was once the Soviet Union. The trouble is that the CIS seems never to meet. Even last year's Start I treaty has not yet won its approval. The US Senate is hardly likely to give the treaties a hearing until there is some action in Minsk (the formal seat of the CIS). Peace and tranquillity are postponed until then.

So the true significance of this week's signing ceremony is the reminder it should provide of the ambiguity of the exSoviet republics on nuclear weapons. During the past year, the republics have been zealous at appropriating to themselves ex-Soviet equipment lying on their territory. The Ukraine, in military strength next only to Russia, has said it has no wish to be a free-standing nuclear power, but has asserted rights to the weapons left on its territory. As time passes and nothing much happens at Minsk, the Ukraine and other republic governments must be tempted to regard their "own" nuclear weapons as a symbolic counterpoise to the power that remains in Moscow. At the very least, Yeltsin would have to ask them nicely even formally to agree to a continuation of present arrangements for control and command of them. The republics would not readily give up the right to ask for something in return.

That is why the most urgent task for the diplomats who have worked up Start II is to create the kind of forum in which the republic governments can be properly engaged in discussions of the strategic relationship of the CIS with the outside world. If Minsk remains inactive, why not arrange a separate forum, at Geneva or elsewhere? Boringly for those concerned, in such a setting it would be necessary to re-educate a new set of participants from the East in the arguments for believing that Start II is in everybody's interests. Meanwhile, Sunday's signing ceremony will have been symbolic only.

\section{Gallo on the rack}

The latest government pronouncement raises questions about the office itself as well as about Gallo.

THE dictum that to be just, justice must be swift seems not to apply to Robert C. Gallo, the researcher at the US National Institutes of Health (NIH). The latest opinion (see page 3) from the Office of Research Integrity (ORI) within NIH's parent body, the Department of Health and Human Services, is another setback for him, but an inconclusive one. Gallo says that the half-sentence now called a "lie" has been misunderstood. In due course, his lawyers may help him make his explanation stick. Last May, a committee of the NIH accepted it.

Last May's report, leaked in unfinished form, was most damaging of Gallo for what it had to say about the management of his laboratory during the period in the 1980s when the hunt for the AIDS virus engaged everybody's attention there. It was a laboratory in which mistakes such as the misattribution of samples could easily have happened. That does not, of course, imply that Gallo or anybody else knowingly misappropriated Montagnier's virus, then called LAV. Nor does sloppiness constitute misconduct. But that also explains why Gallo has been unable to prove that his virus and that of Luc Montagnier of the Institut Pasteur have independent origins. Gallo's initial disbelief of Montagnier's claim to have isolated a virus from AIDS patients, which he has since acknowledged to have been unfortunate, inevitably colours the dispute that has rumbled on since 1984 .

What should happen now? Gallo's energy and resources were crucial in the speedy identification of the virus responsible for AIDS, and for the diagnostic tools in use since the second half of 1984. But Gallo's estimation of his own laboratory's progress was immodest, while Montagnier deserved more credit than Gallo gave him. It is futile to expect that further parsing of the literature can decide whether Gallo and/or his associates knowingly used Montagnier's virus as their own. The practical question now is simply whether the equal division of royalties between France and the United States, agreed in 1986, should persist. The notion that a federal investigative office can function as a universal Solomon is even less tenable now than when it belonged to NIH. 